\title{
Awareness of Neural Tube Defects in Family Physicians
}

\author{
Izzet Goker Kucuk ${ }^{1^{*}}$, Utku Eser ${ }^{2}$, Murat Cevik ${ }^{3}$, Kurtulus Ongel $^{4}$
}

\footnotetext{
${ }^{1}$ Kemaloz Family Health Center, Usak, Turkey

${ }^{2}$ Usak University, Faculty of Medicine, Department of Family Medicine, Usak, Turkey

${ }^{3}$ Gudul Family Health Center, Gudul, Ankara, Turkey

${ }^{4}$ Izmir Katip Celebi University, Faculty of Medicine, Department of Family Medicine, Izmir, Turkey
}

\section{Correspondence:}

Izzet Goker Kucuk

Address: Kemaloz Family Health Center, Usak, Turkey

Email: izzetgoker@gmail.com

Received: 10.04.2020,

Accepted: 25.11.2020

https://doi.org/10.29333/jcei/9707

\section{ABSTRACT}

Objective: The aim of this study was to measure the knowledge level of physicians working in family health centers about the conditions leading to neural tube defect (NTD) and preventive measures.

Material and Methods: In this cross-sectional study, 406 general practitioners and family medicine specialists made a survey consisted of 13 questions. Chi-square, Fisher's Exact test and Pearson chi-square analysis were applied as statistical methods.

Results: A total of 406 physicians (family medicine specialists: 110, general practitioners: 296) participated in the study. $81.53 \%$ of the participants were working in a city and $18.47 \%$ were working in the countryside. The number of referral to general practitioners before pregnancy was significantly higher than that of family medicine specialists. $(p<0.05) .36 .95 \%$ of the respondents knew that the neural tube was closed in the first month of embryological life. Folic acid initiation rate was $99.26 \%$ for patients planning pregnancy. Initiation of vit B12 with folic acid was $28.33 \%$ in patients planning pregnancy. The rate of knowing that vitamin B12 deficiency causes NTD was $39.41 \%$ (family medicine specialists: $50 \%$, general practitioners: $35.47 \%)$, and FMSs were statistically significant $(p<0.05)$.

Discussion: While the number of pregnant women who received folic acid only was sufficient, the number of pregnant women who took vitamin B12 with folic acid was very low. Family medicine specialists and general practitioners had insufficient knowledge that using vitamin B12 in combination with folic acid prevented NTD development. By preparing and implementing algorithms that can prevent NTDs, many life-long complications can be prevented.

Keywords: family medicine, folic acid, neural tube defect, vitamin B12

\section{INTRODUCTION}

Neural tube defects (NTD) develop on the first 28th day of embryological life when the neural tube that needs to be closed remains open [1]. Genetic and environmental factors are considered responsible in the etiology [2]. Although there are various mutations among genetic factors, it is not clearly proven; however, maternal age lower than 19 years and older than 40 years considered as a risk factor $[3,4]$ Among environmental factors; low folic acid, vitamin B 2-6-12, choline, betaine, $n-3$ polyunsaturated fatty acids, zinc and vitamin $\mathrm{D}$ levels and high homocysteine levels are seen in neural tube defects $[2,5,6]$. Although the frequency of NTD is $1 / 1000$, its frequency may vary between $0.2-10 \%$ in various regions of the world [7]. It is very important to take necessary precautions before and during pregnancy in order to prevent NTDs due to mortality and serious morbidities. Because of this serious effects, Republic of Turkey Ministry of Health started a support program for folic acid intake during pregnancy, since 1999 [8].

To prevent NTD, it is necessary encourage to intake B2-6-12 vitamins, choline, betaine and n-3 polyunsaturated fatty acids which are using folic acid together with single carbon metabolism. Genetic screening is recommended because of the possibility that the polymorphism in a single carbon mechanism may lead to the development of NTD. Other conditions that may contribute to the development of NTD include the consumption of alcohol, tea and coffee in women of childbearing age and the low consumption of fruits and vegetables 
$[9,10,11,12]$. The risk of NTD may increase due to folic acid and vitamin B12 deficiency in women who have undergone bariatric surgery [13]. Peker E et al. showed that, NTD folic acid and vitamin B12 with low levels of homocysteine was found to be accompanied with elevated levels [14]. At the 28th day of gestation, 6 NTD children can be born in every 10000 live births with the values of the erythrocyte folate level above $1000 \mathrm{nmol} / \mathrm{L}$, and when this value drops to 500 $\mathrm{nmol} / \mathrm{L}$, an average of 25.4 NTD children is born [15]. NTD is a serious health problem and brings moral and material burden for family and society. Pregnancy tracking is done by family physicians in Turkey is a sharp maintained [16].

The aim of this study is to determine the levels of knowledge all doctors (general practitioner / family medicine specialist) working as a family doctor about folic acid and vit B12, which should be given during the first trimester of pregnancy and in the periconceptional period for prevention of NTDs.

\section{MATERIALS AND METHODS}

The cross-sectional study was carried out according to the permission of İzmir Katip Çelebi University Noninvasive Clinical Research Ethics Committee dated 10.10.2018 and numbered 323 decision. The criteria for inclusion in the study were to be an active family physician in primary care, and the maximum number of clinicians was tried to be reached by performing snowball sampling between 1 November 2018 and 1 December 2018. The study was initiated by two authors working as family physicians in primary care and reached a total of 406 clinicians (family medicine specialists: 110 , general practitioners: 296).

The study was conducted by using the survey application on the internet. The survey was conducted on general practitioners and family medicine specialists who performed family medicine in a period of 1 month between 1 November 2018 and 1 December 2018. In this study, which was determined as cross-sectional type, a questionnaire consisting of 13 questions was applied by the family physicians in order to evaluate the neural tube defect awareness after the informed consent form was obtained. The first 5 questions are about socio-demographic data and the remaining 8 questions are related to the level of knowledge of neural tube defects. Persons with known psychiatric illnesses, those with deficiencies in the questionnaire and non-volunteers were excluded from the study. The data obtained in this study were analyzed with IBM SPSS Statistics Version 22 package program.

The chi-square analysis was applied to examine the relationships between the groups of nominal variables. Fisher's Exact Test was used in cases where the expected values in the eyes were not sufficient in $2 \times 2$ cross tables and in the $\mathrm{RxC}$ tables Pearson chi-square analysis was applied with the help of Monte Carlo Simulation. When interpreting the results, 0.05 was used as the level of significance.

\section{Neural Tube Defect Awareness Form}

1. What is your age?

2. What is your gender? male or female

3. The area where you work? City / Rural

4. How many years have you been working as a doctor? year

5. What is your education status?

a. Family medicine specialist

b. General practitioner

6. What percentage of your pregnant patients apply to you before pregnancy?
a. $0-24.9 \%$
b. $25-49.9 \%$
c. $50-74.9 \%$
d. $75-100 \%$

7. When does the neural tube close in embryological life?
a. At the end of 1st month
b. At the end of the 2 nd month
c. At the end of the 3rd month

8. Do you look at the folic acid levels of your patients planning pregnancy? Yes / No

9. Do you start folic acid for your patients planning pregnancy? Yes / No

10. When do you start folic acid?
a. I start if the folate level is low
b. I start if the folate level is normal
c. I want her to see an obstetrician.
d. I start regardless of the folate level

11. Do you look at the vitamin B12 levels of your patients planning pregnancy? Yes / No

12. When do you start vitamin B12?
a. I start if the vitamin B12 level is low
b. I start if the vitamin B12 level is normal
c. I want her to see an obstetrician.
d. I start regardless of the vitamin B12 level

13. Do you know that vitamin B12 deficiency can cause neural tube defects? Yes / No

\section{FINDINGS}

The age of the 406 physicians who were included in the study and the number of years they worked and the sociodemographic characteristics of these physicians were determined in the following tables (Tables 1 and 2).

Age and working years are seen to be significantly higher in general practitioners $(\mathrm{p}<0.05)$. In order to be able to practice family medicine under contract in Turkey, family medicine specialists are given some priorities according to general practitioners. General practitioners, on the other hand, are placed in suitable positions according to the score they get according to their working period. As a result, the age and working time of general practitioners working as family physicians are higher than family medicine specialists. 
Awareness of Neural Tube Defects

Table 1. Distribution of physicians according to age and number of years of work

\begin{tabular}{cccccccc}
\hline & $\mathbf{n}$ & Mean & Median & Min & Max & ss \\
\hline Age & 406 & 39.65 & 40 & 25 & 65 & 8.4 \\
\hline How many years have you been working as a physician? & 406 & 14.79 & 15 & 0.25 & 40 & 8.96 \\
\hline
\end{tabular}

Table 2. Frequency distribution table for demographic information

\begin{tabular}{|c|c|c|c|}
\hline & & $\mathbf{n}$ & $\%$ \\
\hline \multirow{3}{*}{ Gender } & Male & 219 & 53.94 \\
\hline & Female & 187 & 46.06 \\
\hline & Total & 406 & 100 \\
\hline \multirow{3}{*}{ Your region } & City & 331 & 81.53 \\
\hline & Rural & 75 & 18.47 \\
\hline & Total & 406 & 100 \\
\hline \multirow{3}{*}{ Education status } & Family medicine specialist & 110 & 27.09 \\
\hline & General practitioner & 296 & 72.91 \\
\hline & Total & 406 & 100 \\
\hline \multirow{5}{*}{$\begin{array}{l}\text { What\% of your patients who are planning pregnancy } \\
\text { apply to you before pregnancy? }\end{array}$} & $0-25$ & 312 & 76.85 \\
\hline & $25-50$ & 56 & 13.79 \\
\hline & $50-75$ & 21 & 5.17 \\
\hline & $75-100$ & 17 & 4.19 \\
\hline & Total & 406 & 100 \\
\hline \multirow{4}{*}{$\begin{array}{l}\text { The neural tube closes in which month of embryological } \\
\qquad \text { life? }\end{array}$} & 1. month & 150 & 36.95 \\
\hline & 2. month & 57 & 14.04 \\
\hline & 3. month & 199 & 49.01 \\
\hline & Total & 406 & 100 \\
\hline \multirow{3}{*}{$\begin{array}{l}\text { Do you start giving folic acid on your patients planning } \\
\text { pregnancy? }\end{array}$} & Yes & 403 & 99.26 \\
\hline & No & 3 & 0.74 \\
\hline & Total & 406 & 100 \\
\hline \multirow{5}{*}{ When do you start giving folic acid? } & I'm starting if the folate level is missing & 32 & 7.94 \\
\hline & I'm starting if the folate level is normal & 55 & 13.65 \\
\hline & I want him to apply to another center & 1 & 0.25 \\
\hline & Regardless of the folate level & 315 & 78.16 \\
\hline & Total & 403 & 100 \\
\hline \multirow{3}{*}{$\begin{array}{l}\text { Do you start giving vitamin B12 when you start giving } \\
\text { folic acid to your patients who are planning pregnancy? }\end{array}$} & Yes & 115 & 28.33 \\
\hline & No & 291 & 71.67 \\
\hline & Total & 406 & 100 \\
\hline \multirow{5}{*}{ When do you start giving Vitamin B12? } & I'm starting if the Vit B12 level is missing & 309 & 76.11 \\
\hline & I'm starting if the Vit B12 level is normal & 19 & 4.68 \\
\hline & I want him to apply to another center & 14 & 3.45 \\
\hline & I start prophylactically regardless of Vit B12 & 64 & 15.76 \\
\hline & Total & 406 & 100 \\
\hline \multirow{3}{*}{$\begin{array}{l}\text { Do you know that vitamin B12 deficiency can make } \\
\text { neural tube defects (NTD)? }\end{array}$} & Yes & 160 & 39.41 \\
\hline & No & 246 & 60.59 \\
\hline & Total & 406 & 100 \\
\hline
\end{tabular}

After sociodemographic features; The chi-square test results of the relationship between the study area and the variables were examined and no statistical significance was found with any parameter (Table 3). 


\begin{tabular}{|c|c|c|c|c|c|c|c|c|}
\hline & & \multicolumn{5}{|c|}{ Your region } & \multirow{2}{*}{\multicolumn{2}{|c|}{ Chi Square Test }} \\
\hline & & \multicolumn{2}{|c|}{ City } & \multicolumn{2}{|c|}{ Rural } & Total & & \\
\hline & & $\mathbf{n}$ & $\%$ & $\mathbf{n}$ & $\%$ & $\%$ & Chi Square & p \\
\hline \multirow{3}{*}{$\begin{array}{c}\text { Do you start giving folic acid } \\
\text { on your patients planning } \\
\text { pregnancy? }\end{array}$} & Yes & 328 & 99.09 & 75 & 100 & 40399.26 & \multirow{3}{*}{$\begin{array}{l}\text { Fisher's } \\
\text { exact }\end{array}$} & \multirow{3}{*}{1} \\
\hline & No & 3 & 0.91 & 0 & 0 & 0.74 & & \\
\hline & Total & 331 & 100 & 75 & 100 & $406 \quad 100$ & & \\
\hline \multirow{5}{*}{$\begin{array}{l}\text { When do you start giving folic - } \\
\text { acid? }\end{array}$} & $\mathrm{I}^{\prime} \mathrm{m}$ starting if the folate level is missing & 30 & 9.15 & 2 & 2.67 & $\begin{array}{ll}32 & 7.94\end{array}$ & \multirow{5}{*}{$*$} & \multirow{5}{*}{0.144} \\
\hline & I'm starting if the folate level is normal & 48 & 14.63 & 7 & 9.33 & $55 \quad 13.65$ & & \\
\hline & I want him to apply to another center & 1 & 0.3 & 0 & 0 & 0.25 & & \\
\hline & Regardless of the folate level & 249 & 75.91 & 66 & 88 & 31578.16 & & \\
\hline & Total & 328 & 100 & 75 & 100 & $403 \quad 100$ & & \\
\hline \multirow{3}{*}{$\begin{array}{l}\text { Do you start giving vitamin } \\
\text { B12 when you start giving folic } \\
\text { acid to your patients who are } \\
\text { planning pregnancy? }\end{array}$} & Yes & 97 & 29.31 & 18 & 24 & $115 \quad 28.33$ & \multirow{3}{*}{0.606} & \multirow{3}{*}{0.436} \\
\hline & No & 234 & 70.69 & 57 & 76 & 29171.67 & & \\
\hline & Total & 331 & 100 & 75 & 100 & 406100 & & \\
\hline \multirow{5}{*}{$\begin{array}{c}\text { When do you start giving } \\
\text { Vitamin B12? }\end{array}$} & I'm starting if the Vit B12 level is missing & 254 & 76.74 & 55 & 73.33 & 30976.11 & \multirow{5}{*}{$*$} & \multirow{5}{*}{0.403} \\
\hline & I'm starting if the Vit B12 level is normal & 16 & 4.83 & 3 & 4 & 194.68 & & \\
\hline & I want him to apply to another center & 9 & 2.72 & 5 & 6.67 & $14 \quad 3.45$ & & \\
\hline & I start prophylactically regardless of Vit B12 & 52 & 15.71 & 12 & 16 & $\begin{array}{ll}64 & 15.76\end{array}$ & & \\
\hline & Total & 331 & 100 & 75 & 100 & $406 \quad 100$ & & \\
\hline \multirow{3}{*}{$\begin{array}{c}\text { Do you know that vitamin B12 } \\
\text { deficiency can make neural } \\
\text { tube defects (NTD)? }\end{array}$} & Yes & 131 & 39.58 & 29 & 38.67 & $160 \quad 39.41$ & \multirow{3}{*}{0.021} & \multirow{3}{*}{0.884} \\
\hline & No & 200 & 60.42 & 46 & 61.33 & $246 \quad 60.59$ & & \\
\hline & Total & 331 & 100 & 75 & 100 & $406 \quad 100$ & & \\
\hline
\end{tabular}

The statistical relationship between the same variables and the educational status was also investigated (Table 4). There was a statistically significant relationship between the educational status and the rate of referral to the family physician before the pregnancy $(\mathrm{p}<0.05)$. There was a statistically significant relationship between the educational status and the knowledge that vitamin B12 deficiency could perform neural tube defect (NTD) $(\mathrm{p}<0.05)$. No statistically significant relationship was found between the educational status of the physician and other parameters.

There is a statistically significant relationship between the educational status and the pre-pregnancy admission rates of patients planning pregnancy $(\mathrm{p}<0.05)$. According to their educational level, $73.64 \%$ and $78.04 \%$ of the patients of family medicine specialists and general practitioners, respectively, and $0-24.9 \%$ of the patients admitted before pregnancy gave the answer.

Although not statistically significant, $74.31 \%$ of family medicine specialists and $79.59 \%$ of general practitioners start folic acid regardless of folate level.

Although not statistically significant, $27.27 \%$ of family medicine specialists and $28.72 \%$ of general practitioners start folic acid while their patients are planning pregnancy, along with vitamin $\mathrm{B} 12$.

There is a statistically significant relationship between educational status and knowing that Vitamin B12 deficiency can cause neural tube defect (NTD) $(\mathrm{p}<0.05) .50 \%$ of family medicine specialists and $35.37 \%$ of general practitioners know that vitamin B12 deficiency can cause neural tube defect (NTD).

\section{DISCUSSION}

Approximately $2 / 3$ of the participants in the study had a lack of knowledge about neural tube embryology. General practitioners, in particular, lacked more information about the relationship between vitamin B12 and neural tube defects than family medicine specialists. Almost all participants had sufficient knowledge about the relationship between folic acid and neural tube defects.

Patients who are planning pregnancy should apply to the family doctor before delivery for healthy pregnancy and after performing the necessary tests, various treatments should be applied accordingly. As in all over the world, in our country, the number of applications to family physicians before pregnancy is low. The most common reason for this is the unintended pregnancies. Unwanted pregnancy rates were $34 \%$ in Western Europe, 54\% in Eastern Europe and 45\% in the United States in 2011 [17,18]. Similarly, 76.85\% of Family Physicians (family medicine specialists and general practitioners) stated that only $0-24,9 \%$ of their patients planning pregnancy had referred to the family physician before pregnancy. 
Awareness of Neural Tube Defects

Table 4. Chi-square test result of relationship between educational status and variables

\begin{tabular}{|c|c|c|c|c|c|c|c|c|c|}
\hline & & \multicolumn{6}{|c|}{ Education status } & \multirow{2}{*}{\multicolumn{2}{|c|}{ Chi Square Test }} \\
\hline & & \multicolumn{2}{|c|}{$\begin{array}{c}\text { Family medicine } \\
\text { specialist }\end{array}$} & \multicolumn{2}{|c|}{ General practitioner } & \multicolumn{2}{|c|}{ Total } & & \\
\hline & & $\mathrm{n}$ & $\%$ & $\mathbf{N}$ & $\%$ & $\mathbf{n}$ & $\%$ & Chi Square & $p$ \\
\hline \multirow{5}{*}{$\begin{array}{l}\text { What } \% \text { of your patients who } \\
\text { are planning pregnancy apply } \\
\text { to you before pregnancy? }\end{array}$} & $0-25$ & 81 & 73.64 & 231 & 78.04 & 312 & 76.85 & \multirow{5}{*}{9.276} & \multirow{5}{*}{0.026} \\
\hline & $25-50$ & 18 & 16.36 & 38 & 12.84 & 56 & 13.79 & & \\
\hline & $50-75$ & 10 & 9.09 & 11 & 3.72 & 21 & 5.17 & & \\
\hline & $75-100$ & 1 & 0.91 & 16 & 5.41 & 17 & 4.19 & & \\
\hline & Total & 110 & 100 & 296 & 100 & 406 & 100 & & \\
\hline \multirow{4}{*}{$\begin{array}{c}\text { The neural tube closes in } \\
\text { which month of embryological } \\
\text { life? }\end{array}$} & 1. month & 42 & 38.18 & 108 & 36.49 & 150 & 36.95 & \multirow{4}{*}{0.101} & \multirow{4}{*}{0.951} \\
\hline & 2.month & 15 & 13.64 & 42 & 14.19 & 57 & 14.04 & & \\
\hline & 3.month & 53 & 48.18 & 146 & 49.32 & 199 & 49.01 & & \\
\hline & Total & 110 & 100 & 296 & 100 & 406 & 100 & & \\
\hline \multirow{3}{*}{$\begin{array}{c}\text { Do you start giving folic acid } \\
\text { on your patients planning } \\
\text { pregnancy? }\end{array}$} & Yes & 109 & 99.09 & 294 & 99.32 & 403 & 99.26 & \multirow{3}{*}{$\begin{array}{l}\text { Fisher's } \\
\text { exact }\end{array}$} & \multirow{3}{*}{1} \\
\hline & No & 1 & 0.91 & 2 & 0.68 & 3 & 0.74 & & \\
\hline & Total & 110 & 100 & 296 & 100 & 406 & 100 & & \\
\hline \multirow{5}{*}{$\begin{array}{l}\text { When do you start giving folic } \\
\text { acid? }\end{array}$} & $\begin{array}{l}\text { I'm starting if the folate } \\
\text { level is missing }\end{array}$ & 10 & 9.17 & 22 & 7.48 & 32 & 7.94 & \multirow{5}{*}{$*$} & \multirow{5}{*}{0.632} \\
\hline & $\begin{array}{l}\text { I'm starting if the folate } \\
\text { level is normal }\end{array}$ & 18 & 16.51 & 37 & 12.59 & 55 & 13.65 & & \\
\hline & $\begin{array}{l}\text { I want him to apply to } \\
\text { another center }\end{array}$ & 0 & 0 & 1 & 0.34 & 1 & 0.25 & & \\
\hline & $\begin{array}{l}\text { Regardless of the folate } \\
\text { level }\end{array}$ & 81 & 74.31 & 234 & 79.59 & 315 & 78.16 & & \\
\hline & Total & 109 & 100 & 294 & 100 & 403 & 100 & & \\
\hline \multirow{3}{*}{$\begin{array}{l}\text { Do you start giving vitamin } \\
\text { B12 when you start giving folic } \\
\text { acid to your patients who are } \\
\text { planning pregnancy? }\end{array}$} & Yes & 30 & 27.27 & 85 & 28.72 & 115 & 28.33 & \multirow{3}{*}{0.082} & \multirow{3}{*}{0.774} \\
\hline & No & 80 & 72.73 & 211 & 71.28 & 291 & 71.67 & & \\
\hline & Total & 110 & 100 & 296 & 100 & 406 & 100 & & \\
\hline \multirow{5}{*}{$\begin{array}{c}\text { When do you start giving } \\
\text { Vitamin B12? }\end{array}$} & $\begin{array}{l}\text { I'm starting if the Vit B12 } \\
\text { level is missing }\end{array}$ & 86 & 78.18 & 223 & 75.34 & 309 & 76.11 & \multirow{5}{*}{0.673} & \multirow{5}{*}{0.88} \\
\hline & $\begin{array}{l}\text { I'm starting if the Vit B12 } \\
\text { level is normal }\end{array}$ & 4 & 3.64 & 15 & 5.07 & 19 & 4.68 & & \\
\hline & $\begin{array}{l}\text { I want him to apply to } \\
\text { another center }\end{array}$ & 3 & 2.73 & 11 & 3.72 & 14 & 3.45 & & \\
\hline & $\begin{array}{l}\text { I start prophylactically } \\
\text { regardless of Vit B12 }\end{array}$ & 17 & 15.45 & 47 & 15.88 & 64 & 15.76 & & \\
\hline & Total & 110 & 100 & 296 & 100 & 406 & 100 & & \\
\hline \multirow{3}{*}{$\begin{array}{c}\text { Do you know that vitamin B12 } \\
\text { deficiency can make neural } \\
\text { tube defects (NTD)? }\end{array}$} & Yes & 55 & 50 & 105 & 35.47 & 160 & 39.41 & \multirow{3}{*}{7.088} & \multirow{3}{*}{0.008} \\
\hline & No & 55 & 50 & 191 & 64.53 & 246 & 60.59 & & \\
\hline & Total & 110 & 100 & 296 & 100 & 406 & 100 & & \\
\hline
\end{tabular}

Neural tube closure is a procedure involving highly complex mechanisms [19]. Closure of the neural tube depends on the embryological events occurring during central nervous system formation [20,21]. In the study, $36,95 \%$ of the total participants $(38,18 \%$ of the FMSs, $36,49 \%$ of the general practitioners) answered the closing time of the neural tube correctly. There was no statistically significant difference between the two groups.
The low number of pre-pregnancy visits to family medicine causes lack folic acid and vitamin B12 prophylaxis for preventing the development of NTD. In a study conducted in Germany, only $37.8 \%$ were found to use prenatal folic acid to prevent NTD development [22]. In the study, the majority of patients do not apply to the health institution before pregnancy and do not take folic acid and vitamin B12. In a study published in 1964, it was first reported that NTD, megaloblastic anemia and ablatio 
placenta could develop with a low folic acid level [23]. Low levels of plasma folate and vitamin B12 levels were correlated with cognitive decline, non-comorbid anxiety disorder, depression and neuropathy, preterm delivery and low birth weight $[24,25,26]$. On the other hand, increased intake of folic acid was also associated with some diseases; among them colorectal cancer, hypersensitivity reactions, masking of vitamin B12 deficiency, diabetes and thyroid diseases were seen [27]. The American Medical Association has determined that the maximum daily use of folic acid in nonpregnant adults is $1000 \mathrm{mcg} /$ day [28]. In order to prevent neural tube defects, $400 \mathrm{mcg}$ folic acid supplement should be recommended daily until 12 weeks of gestation [29,30]. According to the Canadian task force report on preventive health services, women with low-risk NTD have a daily dose of $0.4 \mathrm{mg}$ of folic acid daily for women with moderate risk, starting 2-3 months before pregnancy and going through 12 weeks of gestation. In women with high risk, $4 \mathrm{mg}$ folic acid should be supplemented daily [31]. In a study conducted on clinicians working in primary care in Puerto Rico, only $12.1 \%$ of the participants had sufficient knowledge that folic acid use prevented the development of neural tube defects [32]. In a study conducted in Southern Israel, it was seen that $94 \%$ of clinicians working in primary care routinely prescribed folic acid to women of childbearing age, but only $2 \%$ correctly knew that folic acid reduces the risk of developing neural tube defects [33]. In a study conducted on obstetricians, pediatricians and general practitioners in India, only $47.52 \%$ of the participants were aware that folic acid should be used before pregnancy and $11.88 \%$ were aware of the recurrence rate of neural tube defects [34]. In our study, it is seen that almost all of the primary care physicians $99.26 \%$ (99.09\% of family medicine specialists, $99.32 \%$ of general practitioners) gave folic acid to their patients planning pregnancy to prevent the risk of developing neural tube defects.

In the study by Kerr SM et al., It was seen that daily intake of $400 \mathrm{mcg}$ folic acid 28 days before conception and during a subsequent menstruation period decreased the NTD development in fetuses by 4.2 times [35]. In the study conducted by Van Gool JD et al., The folate level in erythrocytes increased to 1050 to $1340 \mathrm{nmol} / \mathrm{L}$, which would provide an optimal decrease in NTD risk in approximately 20 weeks by taking $4 \mathrm{mg}$ folic acid daily. Therefore, they recommended folic acid support to be started 5-6 months before conception [1]. In our study, $78.16 \%$ of the participants $(74.31 \%$ of FMSs, $79.59 \%$ of general practitioners) started to give folic acid supplementation to pregnant patients regardless of blood folate level.

Enrichment of nutrients in folic acid and vit B12 (eg flour) and intake of folate-rich foods (eg green leafy vegetables) may prevent the development of NTD $[36,37,38,39]$. The risk of developing NTD increases with folic acid and vit B12 deficiency due to vegetarian diet [20].
In the study of $\mathrm{Li} \mathrm{K}$ et al., It was found that, taking vitamin $\mathrm{B}$ complex, choline, betaine and n-3 polyunsaturated fatty acids together were more effective instead of folic acid alone to prevent the development of NTD [9]. In the present study, only $28.33 \%$ (27.27\% of FMSs, $28.72 \%$ of GPs) of pregnant women planning pregnancy were started with folic acid and vitamin B12 together. On the other hand, $76,11 \%$ of the pregnant women with vitamin B12 deficiency (FMSs 78.18\%, $75.34 \%$ of the general practitioners) were given vit B12. In contrast to the literature, $50 \%$ of the FMSs and $35.47 \%$ of the general practitioners knew that vitamin B12 deficiency could cause NTD. There was a statistically significant relationship between the two groups ( $\mathrm{p}<0.05)$. There was a statistically significant relationship between the two groups $(\mathrm{p}<0.05)$.

If we look at the strengths of this study; there were no previous studies showing and comparing the level of knowledge of doctors on NTD prevention. It sufficiently represents FMSs who work actively in the health system and GPs who practice family medicine. Among other positive aspects, the knowledge levels of FMSs and GPs in family medicine were determined. The results obtained here can be used in pre-pregnancy counseling services in family medicine, in pregnant follow-ups, in family medicine specialty training and in-service training of family practitioners.

The low number of pre-pregnancy counseling services caused low rates of folic acid and vit B12 intake. According to the regions where some of the physicians participated, blood folate and vit B12 levels were not available. Afterwards, it is necessary to pay attention to the points mentioned in the planning of the studies to be carried out and to be carried out on larger groups.

\section{CONCLUSION}

While the clinicians participating in the study, start prescribing folic acid to almost all of the women who are planning pregnancy, only $28.33 \%$ of clinicians prescribe vitamin B12. Half of the family medicine specialists and about $2 / 3$ of the general practitioners do not know that vitamin B12 deficiency can cause neural tube defects. We think that this issue should be emphasized during the obstetrics and gynecology rotation of family medicine specialization curricula. General practitioners had more insufficient knowledge of the relationship between vitamin B12 and neural tube defects, compared to family medicine specialists. In order to eliminate these deficiencies, this issue should be included in the regular in-service trainings of the Ministry of Health. During the regular supervision of family physicians conducted by the ministry of health, we think that the prescribing vitamin B12 and monitoring the B12 levels must be among the mandatory criteria for pregnancy monitoring which is included in the performance reviews of family physicians.

Declaration of interest: The authors report no conflicts of interest.

Financial Disclosure: No financial support was received. 


\section{REFERENCES}

1. Van Gool JD, Hirche H, Lax H, De Schaepdrijver L. Folic acid and primary prevention of neural tube defects: A review. Reprod Toxicol. 2018 Sep; 80: 73-84. doi: 10.1016/j.reprotox.2018.05.004.

2. Sirinoglu HA, Pakay K, Aksoy M, Bakırci IT, Ozkaya E, Sanverdi I. Comparison of serum folate, $25-\mathrm{OH}$ vitamin $\mathrm{D}$, and calcium levels between pregnants with and without fetal anomaly of neural tube origin. J Matern Fetal Neonatal Med. 2018 Jun; 31(11): 1490-3. doi: 10.1080/14767058.2017.1319924.

3. Frey L, Hauser WA. Epidemiology of neural tube defects. Epilepsia. 2003; 44 Suppl 3: 4-13. doi: 10.1046/j.1528-1157.44.s3.2.x.

4. Vieira AR, Castillo Taucher S. Edad materna y defectos del tubo neural: evidencia para un efecto mayor en espina bífida que anencefalia [Maternal age and neural tube defects: evidence for a greater effect in spina bifida than in anencephaly]. Rev Med Chil. 2005; 133(1): 6270. doi: $10.4067 /$ s0034-98872005000100008.

5. Greene ND, Copp AJ. Neural tube defects. Annu Rev Neurosci. 2014; 37: 221-42. doi: 10.1146/annurevneuro-062012-170354.

6. Li H, Zhang J, Niswander L. Zinc deficiency causes neural tube defects through attenuation of p53 ubiquitylation. Development. 2018 Dec 13; 145(24): dev169797. doi: 10.1242/dev.169797.

7. Copp AJ, Stanier P, Greene ND. Neural tube defects: recent advances, unsolved questions, and controversies. Lancet Neurol. 2013 Aug; 12(8): 799-810. doi: 10.1016/S1474-4422(13)70110-8.

8. Turan JM, Say L, Bulut A. Folic Acid Use of Neural Tube Defects. Available at: http://www.ttb.org.tr/STED/ sted0800/2.html

9. Li K, Wahlqvist ML, Li D. Nutrition, One-Carbon Metabolism and Neural Tube Defects: A Review. Nutrients. 2016 Nov 23; 8(11), 741. doi: 10.3390/nu8110741

10. Nasri K, Ben Fradj MK, Touati A, Aloui M, Ben Jemaa $\mathrm{N}$, Masmoudi A, et al. Association of maternal homocysteine and vitamins status with the risk of neural tube defects in Tunisia: A case-control study. Birth Defects Res A Clin Mol Teratol. 2015 Dec; 103(12): 1011-20. doi: 10.1002/bdra.23418.

11. Imbard A, Benoist JF, Blom HJ. Neural tube defects, folic acid and methylation. Int J Environ Res Public Health. 2013 Sep 17; 10(9): 4352-89. doi: 10.3390/ijerph10094352.

12. Drews K. Folate metabolism--epigenetic role of choline and vitamin B12 during pregnancy. Ginekol Pol. 2015 Dec; 86(12): 940-6. doi: 10.17772/gp/60561.
13. Jans G, Matthys C, Bogaerts A, Lannoo M, Verhaeghe J, Van der Schueren B. Maternal micronutrient deficiencies and related adverse neonatal outcomes after bariatric surgery: a systematic review. Adv Nutr. $2015 \mathrm{Jul}$ 15; 6(4): 420-9. doi: 10.3945/an.114.008086.

14. Peker E, Demir N, Tuncer O, Üstyol L, Balahoroğlu R, Kaba S, et al. The levels of vitamin B12, folate and homocysteine in mothers and their babies with neural tube defects. J Matern Fetal Neonatal Med. 2016 Sep; 29(18): 2944-8. doi: 10.3109/14767058.2015.1109620.

15. Crider KS, Devine O, Hao L, Dowling NF, Li S, Molloy $\mathrm{AM}$, et al. Population red blood cell folate concentrations for prevention of neural tube defects: bayesian model. BMJ. 2014; 349: g4554. doi: 10.1136/bmj.g4554.

16. https://www.mevzuat.gov.tr/mevzuat?MevzuatNo=170 51\&MevzuatTur=7\&MevzuatTertip=5 (Accessed: 13 July 2020).

17. Baird DT, Bajos N, Cleland J, Glasier A, La Vecchia C, Leridon $\mathrm{H}$, et al. Why after 50 years of effective contraception do we still have unintended pregnancy? A European perspective. Hum Reprod. 2018 May 1; 33(5): 777-83. doi: 10.1093/humrep/dey089.

18. Finer LB, Zolna MR. Declines in Unintended Pregnancy in the United States, 2008- 2011. N Engl J Med. 2016 March 3; 374(9): 843-52. doi: 10.1056/NEJMsa1506575.

19. Nikolopoulou E, Galea GL, Rolo A, Greene ND, Copp AJ. Neural tube closure: cellular, molecular and biomechanical mechanisms. Development. 2017 Feb 15; 144(4): 552-66. doi: 10.1242/dev.145904.

20. Yamaguchi $Y$, Miyazawa H, Miura M. Neural tube closure and embryonic metabolism. Congenit Anom (Kyoto). 2017 Sep; 57(5): 134-7. doi: 10.1111/cga.12219.

21. Akan N. It can reduce the risk of giving birth to babies with neural tube defects. Journal of Cumhuriyet University School Of Nursing 2002; 6: 42-8. Available at: http://eskidergi.cumhuriyet.edu.tr/makale/602.pdf

22. Birkenberger A, Henrich W, Chen F. Folic Acid Intake Among Women in Berlin According to Their SocioEconomic Status. Z Geburtshilfe Neonatol. 2018 Nov 16. doi: 10.1055/a-0750-6376.

23. Hibbard BM. The role of folic acid in pregnancy, with particular reference to anaemia, abruption and abortion. J Obstet Gynaecol Br Commonw 1964; 71: 529-42. doi: 10.1111/j.1471-0528.1964.tb04317.x.

24. Bjelland I, Tell GS, Vollset SE, Refsum H, Ueland PM. Folate, vitamin B12, homocysteine, and the MTHFR 677C-> T polymorphism in anxiety and depression: the Hordaland Homocysteine Study. Arch Gen Psychiatry. 2003 Jun; 60(6): 618-26. doi: 10.1001/archpsyc.60.6.618.

25. Sobczyńska-Malefora A, Harrington DJ. Laboratory assessment of folate (vitamin B9) status. J Clin Pathol. 2018 Nov; 71(11): 949-56. doi: 10.1136/jclinpath-2018205048 . 
26. Banjari I, Matoković V, Škoro V. The question is whether intake of folic acid from diet alone during pregnancy is sufficient. Med Pregl. 2014 Sep-Oct; 67(910): 313-21. doi: 10.2298/MPNS1410313B.

27. Boyles AL, Yetley EA, Thayer KA, Coates PM. Safe use of high intakes of folic acid: research challenges and paths forward. Nutr Rev. 2016 Jul; 74(7): 469-74. doi: 10.1093/nutrit/nuw015.

28. Orozco AM, Yeung LF, Guo J, Carriquiry A, Berry RJ. Characteristics of U.S. Adults with Usual Daily Folic Acid Intake above the Tolerable Upper Intake Level: National Health and Nutrition Examination Survey, 2003-2010. Nutrients. 2016 Apr 1; 8(4): 195. doi: 10.3390/nu8040195.

29. Kondo A, Matsuo T, Morota N, Kondo AS, Okai I, Fukuda H. Neural tube defects: Risk factors and preventive measures. Congenit Anom (Kyoto). 2017 Sep; 57(5): 150-6. doi: 10.1111/cga.12227.

30. Podgórski R, Stompor M, Kubrak T, Podgórska D. Neural tube defects: risk factors and prevention. Eur J Clin Exp Med 2017; 15(2): 151-6. doi: 10.15584/ejcem.2017.2.9.

31. Wilson RD, Wilson RD, Audibert F, Brock JA, Carroll J, Cartier L, et al. Pre-conception Folic Acid and Multivitamin Supplementation for the Primary and Secondary Prevention of Neural Tube Defects and Other Folic Acid-Sensitive Congenital Anomalies. J Obstet Gynaecol Can. 2015 Jun; 37(6): 534-52. doi: 10.1016/S1701-2163(15)30230-9.

32. Miranda A, Dávila Torres RR, Gorrín Peralta JJ, Montes de Longo I. Puerto Rican primary physicians' knowledge about folic acid supplementation for the prevention of neural tube defects. Birth Defects Res A Clin Mol Teratol. 2003; 67(12): 971-3. doi:10.1002/bdra.10142.
33. Abu-Hammad T, Dreiher J, Vardy DA, Cohen AD. Physicians' knowledge and attitudes regarding periconceptional folic acid supplementation: a survey in Southern Israel. Med Sci Monit. 2008; 14(5): CR262CR267. Available at: https://www.medscimonit.com/ download/index/idArt/855752 PMid:18443550

34. Aggarwal A, Kumhar GD, Harit D, Faridi MM. Role of folic acid supplementation in prevention of neural tube defects: physicians yet unaware!. J Prev Med Hyg. 2010; 51(3): 131-2. PMid:21361119

35. Kerr SM, Parker SE, Mitchell AA, Tinker SC, Werler MM. Periconceptional maternal fever, folic acid intake, and the risk for neural tube defects. Ann Epidemiol. 2017 Dec; 27(12): 777-82. doi: 10.1016/j.annepidem.2017.10.010.

36. Turner M. Folic acid and vitamin B12 fortification of food for preventing neural tube defects in Europe. BMJ. 2018 Apr 6; 361: k1572. doi: 10.1136/bmj.k1572.

37. Ami N, Bernstein M, Boucher F, Rieder M, Parker L. Folate and neural tube defects: The role of supplements and food fortification. Paediatr Child Health. 2016 Apr; 21(3): 145-54. doi: 10.1093/pch/21.3.145.

38. Osterhues A, Ali NS, Michels KB. The role of folic acid fortification in neural tube defects: a review. Crit Rev Food Sci Nutr. 2013; 53(11): 1180-90. doi: 10.1080/10408398.2011.575966.

39. Deb R, Arora J, Samtani R, Garg G, Saksena D, Sharma $\mathrm{N}$, et al. Folic acid, dietary habits, and homocysteine levels in relation to neural tube defects: A case-control study in North India. Birth Defects Res. 2018 Aug 15; 110(14): 1148-52. doi: 10.1002/bdr2.1373. 